\title{
N.Z NATIONAL SOCIETY FOR EARTHQUAKE ENGINEERING
}

\author{
RECONNAISSANCE TEAMS
}

\author{
PRESENT STATUS OF ORGANISATION
}

In 1974 the Management Committee of the Society authorised the setting up of an earthquake reconnaissance team scheme, whereby a team of suitably experienced observers would be quickly transported to the scene of a damaging earthquake. A sub-committee under Mr. J. P. Hollings was formed and a detailed brief for the scheme was prepared and subsequently adopted by the Management Committee.

Following advertisements in the Bulletin and the New Zealand Engineering, a pool of over 35 suitable observers has been formed. Most of the pool are practising civil and structural engineers though a number of specialists, including three architects, have been included.

The scheme is now fully operational. At present the team orgariser is Mr. J. P. Hollings (Wellington) and his deputy is Mr. N. D. Hardie (Christchurch). Mr. Hollings is also authorised, together with the Fresident, to approve a reconnaissance. It is intended that all pool members will be issued an Engineering Reconnaissance Manual containing information on the administration and aims of the scheme, the action to be taken following a damaging earthquake and a detailed engineering reconnaissance field guide. The following brief is reproduced from the manual; Section one outlines the aims and administration of the scheme and Section Two, procedures to initiate a reconnaissance. These sections together with a budget sufficient to allow reconnaissance of a large earthquake, have been approved by the Management committee.

\section{ENGINEERING RECONNAISSANCE MANUAL}

\section{SECTION ONE : ADMINISTRATION AND AIMS OF THE SCHEME}

\section{Reconnaissance Aims}

The broad aim of an engineering reconnaissance is to record all aspects of earthquake damage and especially to record all information which might otherwise be lost.

Two specific functions can be identified. Firstly the reconnaissance team must record details of earthquake damage which may be lost in reconstruction works, fires, or further earthquakes or during demolition of unsafe structures. Secondly, instances of earthquake damage (or lack of damage) which are important to the current philosophies of earthquake resistance design and which may warrant further investigation should be identified and where necessary a brief prepared for a more detailed investigation to be carried out at a later date.

Detailed investigations of specific occurrences of earthquake damage may be conducted at the discretion of the team leader, though it is not expected that extensive investigations of this kind will be a major part of the reconnaissance. It is recognised, however, that circumstances in the field may dictate the team's activities and the authority of the team leader in this respect is to be complete. The team leader is also responsible for the rapid completion of the reconnaissance report, which should contain the following:- (a) a general review of the effect of the earthquake on engineered structures, services and communications,

(b) a record of earthquake damage which mightotherwise have been lost in reconstruction works, fire or further earthquakes,

(c) an appraisal of instances of earthquake damage which appear important to the current philosophies of earthquake resistant design, and which may warrant further investigation.

(d) a detailed brief for any further investigations, considered necessary, and

(e) reports of detailed investigations carried out, and any further information considered important.

The reconnaissance report should be in a form suitable for publication by the Society either in whole or in part.

\section{Administration}

The Management Committee of the Society will appoint a reconnaissance team organiser to be responsible to the committee for the continuing administration of the reconnaissance team scheme. The team organiser should be a practising engineer and a member of the Management Committee.

Detailed functions of the team organiser will include keeping the details of the pool of approved team members and leaders fully up to date, advertising for new members and ensuring that the alternative organisation procedures (in case the team 
organiser is isolated by an earthquake) are well maintained.

An arrangement has been made with the Ministry of Works and Development for their Operations staff to contact the team organiser or his deputy in the event of a damaging earthquake at the same time as senior M.W.D. staff are notified. The Ministry of Civil Defence has undertaken to provide reconnaissance team members with Civil Defence passes, which ensure entry to restricted areas following a declaration of a civil emergency. It is important that the team organiser maintains these arrangements and that liaison with both organisations continues.

In so far as is possible the team organiser will prepare travel plans and field guides to enable a reconnaissance team to be organised and transported to the epicentral area, and to begin the reconnaissance without delay.

The administration of the reconnaissance team scheme shall be reviewed every 2 years following the election of a new president. Positions to be confirmed by the Management Committee are the President's deputy (the President or his deputy may authorise a reconnaissance), and the organiser and his deputy. The President and his deputy and the team organiser and his deputy must reside in different cities.

\section{Selection of Reconnaissance Team Members}

A reconnaissance team shall be selected from the pool of team members and team leaders. All nominations to the pool must be approved by the Management Committee of the society.

It is expected that most team members will be practising engineers. In the event of a major earthquake damage in a city centre, an architect should be included in the reconnaissance team. Specialised investigations may be recommended by the team leader after the initial reconnaissance. These secondary reconnaissances may require personnel with particular skills or knowledge and it is recommended that applications to join the team member pool from people in this category be encouraged (e.g. H \& V, electrical and soil engineers, material scientists, geologists, etc.).

Team leaders shall have a broad appreciation of structural and civil engineering aseismic design procedures evident by extensive professional experience or by publications which have made significant contributions to the subject. For major earthquakes, previcus reconnaissance experience is required and experience in engineering management desirable.

Although reasonable out of pocket expenses will be reimbursed by the society. reconnaissance team members and leaders will not be paid for their time. Team members are expected to provide cameras, tape recorders, stationery, etc., and the team organiser will provide reconnaissance team pool members with a suggested equipment list. Team members are also expected to be physically fit and be prepared to 'rough it' if necessary.
Members of the team member pool will be required to fill in a standard form outlining their occupation, reconnaissance experience and fields of special knowledge. This information will provide a basis for the selection of balanced reconnaissance teams.

The list of pool members is to be reviewed during the administration review of the scheme every two years.

\section{Action Required Every Two Years:}

Following the election of a new President, the Management Committee will carry out the following review of the reconnaissance team scheme.

(1) Elect a team organiser and a deputy team organiser, (must be in widely separated centres).

(2) Elect a President's deputy to authorise a reconnaissance in the Presidents absence. (President and President's deputy must be in widely separated centres.)

(3) To review the composition of the team leader and team members pools and to make recommendations regarding the possible invitation of further applications for membership. (This task will normally be delegated to a team organiser.)

(4) To conduct a general review (if necessary) of the aims and administration of the scheme in the light of reconnaissance experience and developments in earthquake engineering.

\section{SECTION TWO : PROCEDURES FOLLOWING AN EARTHQUAKE}

\section{Initiation of a Reconnaissance}

The President of the society or his appointed deputy is empowered to authorise a reconnaissance. He will be assisted by the team organiser who will carry out all detailed planning of the reconnaissance including liaison with the D.S.I.R., the Civil Defence Authorities and the M.W.D., to confirm the event and to locate the epicentral area. The team organiser shall take all reasonable measures to ensure the best available reconnaissance team is brought together and transported to the scene of the earthquake as quickly as possible.

The M.W.D. Operations Room in Vogel House, Wellington is placed on a continuous alert following a civil emergency anywhere in N.Z. As outlined in section 1 , the operations staff will notify the team organiser, or his deputy, of a damaging earthquake in N.Z. It is anticipated that communications from the reconnaissance team in the field will use this link should normal toll and telegraph facilities be out of action.

A reconnaisaance of earthquake damage shall generally be necessary only in the event of earthquake damage intensities of MM VIII or more. Both the Geological survey and the seismological observatory have detailed procedures to enable field parties to be placed in the epicentral area of the earthquake within a few hours. Successful 
liaison with these parties may prove invaluable in isolating the areas where maximum damage to engineered structures has occurred.

The reconnaissance team should be able to comment on earthquake damage to buildings, bridges and other structures, engineered services and communications.

It is anticipated that a reconnaissance team will number between 4 and 8 , depending on the early reports of the extent of damage to engineered systems caused by the earthquake. The team organiser should seek the approval of the President for the number in the team. Team numbers may be altered as more information becomes available.

The composition of the team will depend on the nature of the damage. For instance, the balance of structural and civil engineers in a team may depend on whether the earthquake has occurred near a city. Pool members with professional commitments and those who reside in the afflicted area should not generally be asked to assist in the reconnaissance. The team leader shall be appointed by the team organiser in consultation with the President, following a consideration of the size of the team, the apparent extent and location of the earthquake damage.

\section{Travel Arrangements and Field Procedures}

Following a major earthquake there may be difficulties in transporting the reconnaissance team to the damaged area. It is suggested that the team assemble in the main centre closest to the earthquake and use light aircraft or helicopters to reach the epicentral region and if necessary to conduct a preliminary reconnaissance.

Regular communication between the team leader and the Society are encouraged. The number and composition of the team may be altered at any time though the President or his deputy must give his approval.

The Civil Defence pass which all team members will carry (should a civil emergency be declared) will allow the team to move freely within restricted zones and may also provide the holder with some priority for transporation should this be a difficulty. It is extremely important that team members realise that these passes are not lightly issued: relatively few senior government officials have access to restricted areas in a civil emergency. Any abuse of these passes would be very damaging to the Society. Passes bear the holders signature and are not transferable.

The team leader is wholly responsible for the activities of the team and for the preparation of the initial reconnaissance report. It is recommended that the team be kept together until the report is complete. Where possible the team organiser or an appointed deputy shall assist the team leader in administrative matters, inciuding the preparation and publishing of the team report.

Action Following Earthquake:
Defence, Ministry of Works and Development or the D.S.I.R. to ascertain the location of the earthquake and the possible extent of the damage caused.

(2) The team organiser notifies the President of the earthquake and contacts the deputy organiser to confirm that the deputy will not be needed. The team organiser and his deputy must make prior arrangements in detail for communications which will ensure that only one of them has control and therefore only one initiates action.

(3) The team organiser prepares a list of possible reconnaissance team members and chooses a team leader in consultation with the President. The team members are placed on standby.

(4) When the extent of the earthquake damage is confirmed the President's authority is sought to initiate an engineering reconnaissance on a suitable scale and budget.

(5) The team selection is confirmed and the members instructed to assemble at a specified airport as soon as possible.

(6) The team organiser makes further transport arrangements as necessary.

(7) Once despatched the team leader has control of the team in the field and reports back to the team organiser at regular intervals as far as communications allow.

(1) The team organiser checks with Civil 